\title{
Novel Approach for Teaching English Language using Emerging Information and Communication Technologies for Visual Impairment Students
}

\author{
(Enfoque novedoso para la enseñanza del idioma inglés \\ utilizando tecnologías emergentes de información \\ y comunicación para estudiantes con discapacidad visual)
}

\author{
Jorge Cárdenas, ${ }^{1}$ Esteban Inga ${ }^{2}$
}

\begin{abstract}
Nowadays, Higher Education Institutions (HEI) need to be more inclusive from the methodological vision appropriate used in the classroom. Visual impairment students (VIS) become a challenge for teachers who look for incorporating different learning environments. This challenge increases when teaching and learning process to VIS is related to the English language; due to the absence of educational didactic resources available at the school and the lack of knowledge of appropriate teaching methodologies and strategies to develop the different language skills: listening, speaking, reading and writing that go with the educational process in the acquisition of the English language. In accordance with this problem, this research proposes a novel methodological strategy, based on the usage of meaningful learning with emerging technologies as a main guide for students with visual impairment. Thus, the road map of good practices in the use of this methodology will allow establishing a clear process to achieve students' active, meaningful and autonomous participation, using the least time in the teaching-learning process of the English language.
\end{abstract}

\section{Keywords}

Mobile learning; education 4.0; educational informatics; visual impairment; emerging information and communication technologies.

\begin{abstract}
Resumen
Hoy en dia, las Instituciones de Educación Superior (IES) deben ser más inclusivas desde una visión metodológica apropiada utilizada en el aula. De esta manera, los estudiantes con discapacidad visual (EDV) se convierten en un desafío para los maestros que buscan incorporar diferentes ambientes de aprendizaje. Este desafío se incrementa cuando el proceso de enseñanza y aprendizaje para los EDV se relaciona con el idioma inglés; debido a la ausencia de recursos didácticos educativos disponibles en el centro educativo y al desconocimiento de las metodologías y estrategias de enseñanza apropiadas para desarrollar las diferentes habilidades lingüísticas: escuchar, hablar, leer y escribir que acompañan el proceso educativo en la adquisición del idioma inglés. De acuerdo con la presente problemática, esta investigación propone una estrategia metodológica novedosa, basada en el uso del aprendizaje significativo utilizando tecnologías emergentes como guía principal para los alumnos con discapacidad visual. Así, el mapa de ruta de las buenas prácticas en el uso de esta metodología permitirá establecer un proceso claro para lograr una participación activa, significativa y autónoma de los alumnos, utilizando el menor tiempo posible en el proceso de enseñanza-aprendizaje del idioma inglés.
\end{abstract}

\section{Palabras clave}

Aprendizaje móvil; educación 4.0; informática educativa; discapacidad visual; tecnologías emergentes de información y comunicación.

\section{Introduction}

Visual Impairment Students (VIS) face with a lot of difficulties in different learning environments which reduce the options for inclusive education that allows them an active and clear partici- 
pation among students with or without visual impairment (Piper, Bulat, Kwayumba, Oketch, y Gangla, 2019); (Kocyigit y Artar, 2015); (Morgan et al., 2019).

The time required by VIS to acquire the English knowledge incorporates new challenges for teachers who are forced to perform improvised activities when a VIS is presented in their classroom environment; and try to maintain students' attention who do not have such disability is an important task that cannot be dismissed (Johnson et al., 2019), (Moon, 2015), (Jeong, 2017).

These students require a lot of motivation to get significant achievements in their skills and abilities which generate competencies, increase their knowledge and raise the possibility of a real inclusion in a traditional environments where all human beings must develop every day (Jeong, 2017), (Roy y Ghosh, 2019), (Hamam y Cheikhrouhou, 2012).

Teaching a foreign language is another variable to be taken into account in the VIS' learning process; due to the lack of didactic resources available in Higher Education Institutions $(\mathrm{HEl})$ to include these students in a shared environment with students who do not have visual impairment; therefore, it is so important to incorporate a route map to help and guide teacher's task of teaching and learning process of the English language to VIS, which is based on a methodology that incorporates emerging technologies and it is supported under the principles of a vision of Education 4.0 to achieve students inclusion, reduce time and encourage them to go on a cooperative-collaborative environment learning (Simões, Jr., y Member, 2016).

This article is organized as follows: Section II introduces the fundamentals of emerging technologies which support the teaching and learning process. Section III, inclusion methodology is proposed that starts with a strategy of good practices. Section IV result analyses are presented which are based on a state of the art and case of studies. Finally, in section $V$ our article is finished with some conclusions.

Figure 1. Presents the conceptual framework to achieve the inclusion of VIS in an inclusive classroom based on the usage of Information and Communication Technologies (ICT) and the Internet of Things (IOT).

Figure 1. Learning Environment based on an Emerging Environment Methodology and Education 4.0

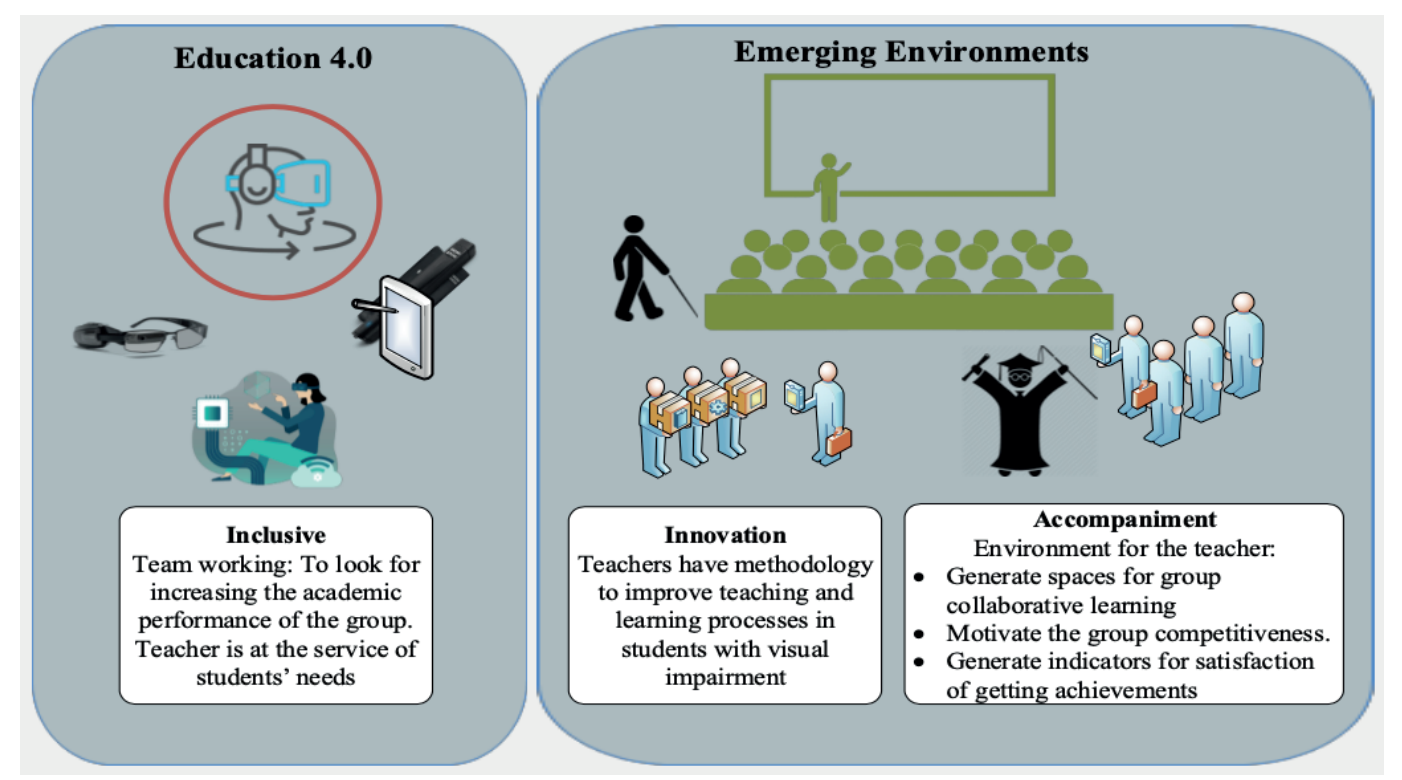

Source: authors 


\section{Emerging Technologies at the Service of Education 4.0}

\section{A. Education 4.0 and ubiquitous learning}

There are several proposals from governments, reforms in education laws, slogans aimed at marketing around the word "inclusion" or "inclusive" but it is a little said how to achieve it, the challenge that it means for the teacher and also the basic requirement that is to maintain the attention of all students with and without visual impairment (Mitra y Cheruvu, 2015).

The change that means today that young people are related to jobs that are not considered in careers yet by Higher Education Institutions (HEI) that will use technologies that are not invented yet or they are as prototypes and seek to solve problems that do not exist yet, the incorporation of new social networks to upload photos, messages, stories, millions of searches per second, connected sensors for internet of things applications (IoT) (Zhou y Zhou, 2017).

Besides, 4G, 5G, $6 G$ and $7 G$ technologies are used with mobile penetration exceeding 92\% of the world's population, App developers serving to the people's needs, an overwhelming knowledge within everyone's reach and doubling every hour, it means an exponential growth of information and technology, the requirement to speak more languages to achieve more information opportunities that will be transformed into knowledge known as big data and data science (Tang \& Pan, 2008), but with all those Information and Communication Technology (ICT) and the Internet of Things (IOT) give opportunities how to achieve an inclusive, more humane, sustainable world that incorporates human beings and we must take into account two fundamental premises related to the VIS, those are: VIS are educated to learn how to live or they are educated to earn a living, that is to say, good people, good citizens are formed, or they must fulfill the title of an undergraduate degree; in this way, education makes them free so that the VIS can find their talent and be incorporated in the route of good living that they feel comfortable as a personal and professional level.

\section{B. Emerging technologies}

Nowadays, people talk about a culture shock because current students have other priorities and they have an absence of attention due to the lack of interest about one or any other subject; this fact cannot be considered in the English language, for its sense of usefulness into their personal and professional life or social relationship with other cultures (Riyanto y Zhang, 2013).

it is also considered a cultural shock because teachers are traditional in an environment with current VIS who are using the ICT and IOT in order to achieve inclusion and motivation by themselves; therefore, a strategy must be achieved so that, the new change or incorporation of technology by English language teachers have to be incorporated into their learning processes.

It implies a need to optimize resources, those which are related with the human capital of teachers, financial capital of HEls, so as not to make unnecessary investments that do not satisfy the parties involved.

It should be remembered that ICT or loT is no longer as a classroom laptop, a projector, or a tablet; at the moment, they are other emerging technology mechanisms for the classroom; such as, skills in data mining, mobile learning (Bai, Lian, Liu, Wang, y Liu, 2018), (Chen, Member, Su, Chen, y Chang, 2019), (Man, 2014), pedagogical innovation based on ICT, web tools for ELearning (Wei, 2014), gamification and simulation (Muttaqin y Suwandi, 2011), virtual learning 
(Riyanto \& Zhang, 2013), educational research, educational neuroscience, education 4.0, leading educational innovation projects (Rizal y Wan, 2013), education and social development among others are important to know.

This changes digital literacy since we live in a society that is strictly articulated with media systems, so it is essential for teachers to understand how each concept and stage of teaching-learning works, it is not as a concept of electronic devices, but as a concept of application to look for students' benefits in general and benefits for VIS in particular.

In this way the teacher must change the paradigm of the traditional teacher, he/she has to understand the type of students who come to class even more if they are VIS. At the present time, the teacher is not the only one who has the knowledge; the teacher has become a companion or facilitator into an interactive teaching-learning process, since students have the facility to download digital information that must be converted into knowledge with the teacher's support in a different manner; this implies the transformation of knowledge or educational revolution.

Knowledge implies collectivity, because it is not only focus on a personalized education, it will refer to a competitive world and it must be learnt to generate multidisciplinary synergies; therefore, students must learn to be creators and innovative people and not to teach them to be technology users (Inga y Hincapié, 2015).

A current question relates to how HEls teach to think and how HEls teach to learn. This is due to the fact that with the knowledge revolution, students must be in a continuous training, so that students in general must have the ability to learn in any place where the teaching process is applied; in this way, a motivation is generated to acquire the knowledge about what it is going to come and finally, it is adapted to what comes regardless of the technological changes that exist, it also goes through an attitude situation to change without any doubt. In other words, it is said that HEls should teach to encourage the critical thinking and incorporate the technological assistance in spaces that could be transformed into places of learning; therefore, new learning experiences should change to traditional methods because students are not the same as they were in past decades and the curriculum cannot be rigid.

It should be a functional curriculum focusing to facilitate the students' development of their potentialities without exception, due to, it is so important to achieve a real principal of an effective inclusive education. An inclusive curriculum is based on the view that learning takes place when all students actively participate in the learning process.

In this way, emerging technologies have become into a tool of scientific innovation that is born every minute and that seeks to solve certain circumstances in which users need to improve or add comfort to their daily performance by incorporating techniques and algorithms based on matching learning or deep learning to automatically solve certain problems put in embedded electronic systems (Agarwal et al., 2017), (Chessa et al., 2016), (Lan, Zhai, y Lin, 2015).

In addition, ubiquitous learning is defined from mobility accompanied by technology; Therefore, the learning articulation and technology generate some possibilities to achieve new objectives and competencies into students, teachers and parents who are included in the educational community, That is why, this work is focused on the use of M-learning as a methodology to reduce learning time in VIS (Mangalathu, Burton, Bauchy, Smedskjaer, y Tandia, 2018), (Miah, 2018), (Lin et al., 2018), additionally, the use of this technology as an academic support is a functional tool that breaks traditional learning processes, taking advantage of the use of different technological applications, which are not necessarily educational, but can be directed toward an educational approach. 


\section{Methodology and Good Practices}

If we start from the fact that an inclusive methodology requires the connectivity of the VIS in a learning environment; it is necessary, to generate knowledge from a true revolution, impacting with the use of technology and thus reducing the time represented by the traditional methods of teaching English language learning. The impact of information and communication technologies (ICTS) and the internet of things loT must be inclusive and also allow teachers to dedicate time to other types of educational innovation through case studies, multidisciplinary work, and entrepreneurship; on other words, to achieve an application of ICTs and loT focus on achieving a genuine inclusive education.

\section{A. The concept of analytical-synthetic good practices}

The teachers' challenge and HEls to insert technology into the process of teaching and learning through the application of Good Practice, A researcher teacher must know how to incorporate emerging technologies with the VIS to integrate them into the learning environment defined as a living environment and motivation to go on in a professional career.

Good practices are directly related to a process of change, necessary adjustments or appropriate adaptations or complementary educational resources to achieve meaningful learning and stimulate students to continue developing their skills and abilities in the knowledge acquisition.

This forces to the teacher to modify, interact and participate actively to satisfy the students' needs through the new technique methodologies using different tools and applications offer by the technology; In this way, it is a good meter the use of new emerging technologies, which fit perfectly into the field of inclusive education, which must be focused on getting goals and objectives to achieve autonomy in ubiquitous learning by VIS.

In order to be a meaningful learning, three fundamental factors need to be understood: reception of knowledge, feedback of it and putting into practice in a real situation what it was learned, It differs from the traditional system in which one of the parties (teacher - student) used to adapt homogeneously; on the other hand, nowadays with the application of ubiquitous learning there is a breaking down of frontiers and barriers in terms of transforming any place into environment learning.

Figure 2 shows how ubiquitous learning in the English language teaching for VIS is directly supported by educational research, which creates a scaffolding with several important components that facilitate the learning process, through embedded systems, whose guarantee of accessibility and performance of the VIS denote an effective work, so that, the different emerging technologies represent a direct connection with the knowledge learned, feedback and applied.

Consequently, the support provided by the E-Learning platform in communion with the apps in an M-Learning environment (which are directly interconnected); they have allowed to demonstrate with valid and sustained data, the incorporation of some activities which were traditionally unreachable and imaginable for an VIS (Ex: Listening, writing exercises and problems which are solving in different formats, such as: multiple choice, matching exercises, complete sentences, word formation, key word transformation, etc.) getting students their autonomous development during the learning process of the English language and they have allowed them to be active in carrying out their work. 
Figure 2. Ubiquitous Learning Methodology for English Language

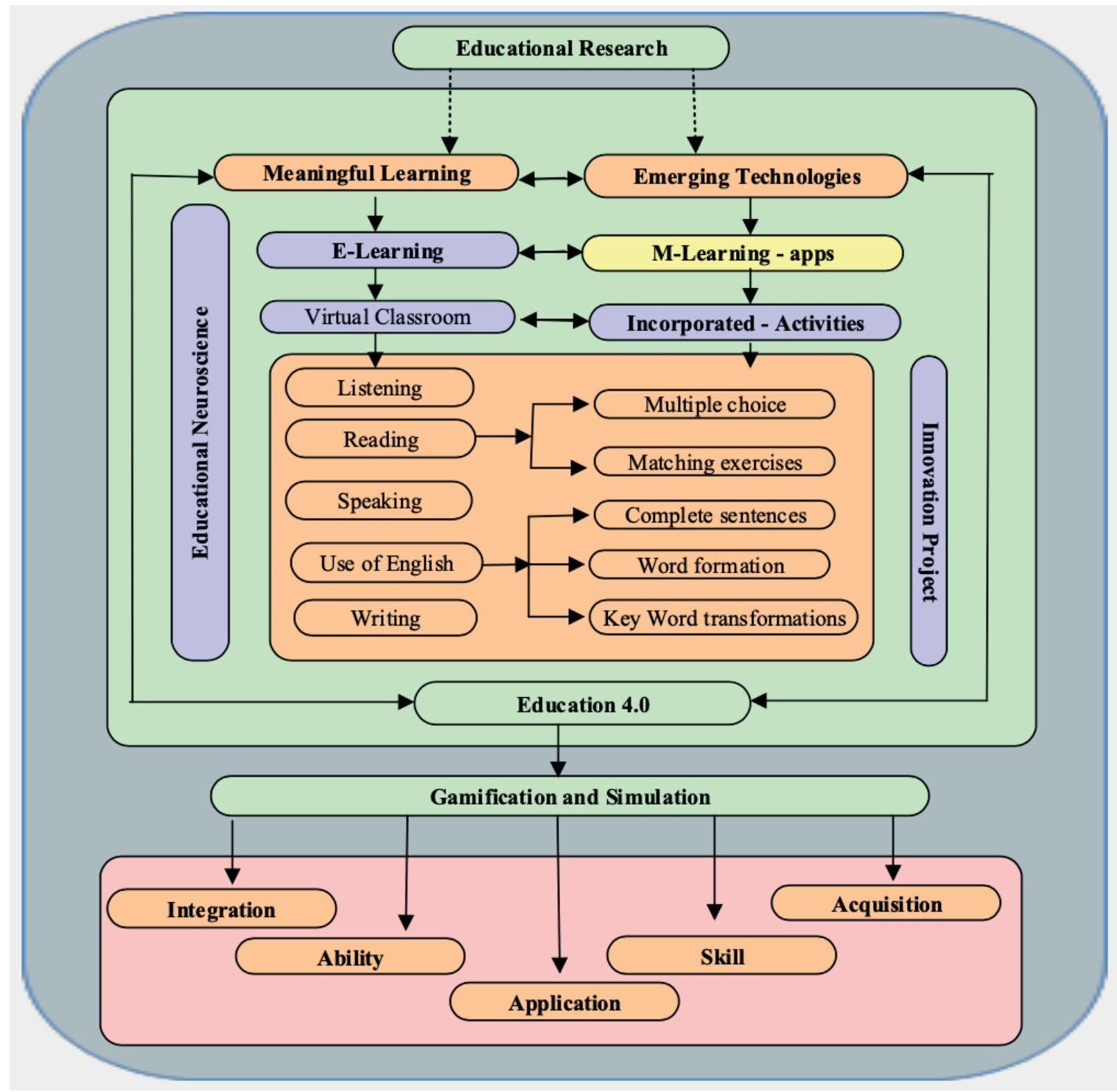

Source: authors

Taking advantage and developing all the educational experience in an integral way, putting into practicing the innovation and changes that Education 4.0 brings with and the usage of the didactic tool as known as the Gamification technique, which allows us to seek ways to increase VIS's motivation through games (Sensory, Orientation and Mobility, html text applications, etc.), applied with the whole group and where they are included, with the aim of achieving improvements in the results of integration, ability, skills, acquisition and application of knowledge that contribute to intrinsic motivation, this particular is raised as innovative projects in the learning of the English language for VIS. 


\section{B. Roadmap for the Inclusion of VIS in English Language Teaching}

If we understand that the future requires a knowledge base to develop in any profession that can be generated with the changes of the revolution of knowledge, it can be said that the English language is a base sustenance to acquire it. This facilitates the inclusion in a heterogeneous environment made up of different students from different degree courses who have focused to achieve knowledge guided or accompanied by a teacher. This particular will give the VIS the basis to face the era of knowledge with vision of the future and achieve the inclusion to different professions because English language is the door to many areas either human or engineering careers.

The virtualization of some careers will allow VIS to acquire knowledge to generate innovation projects and getting inclusion into a society as active members of it.

Figure 3. Roadmap for applying ubiquitous learning methodology

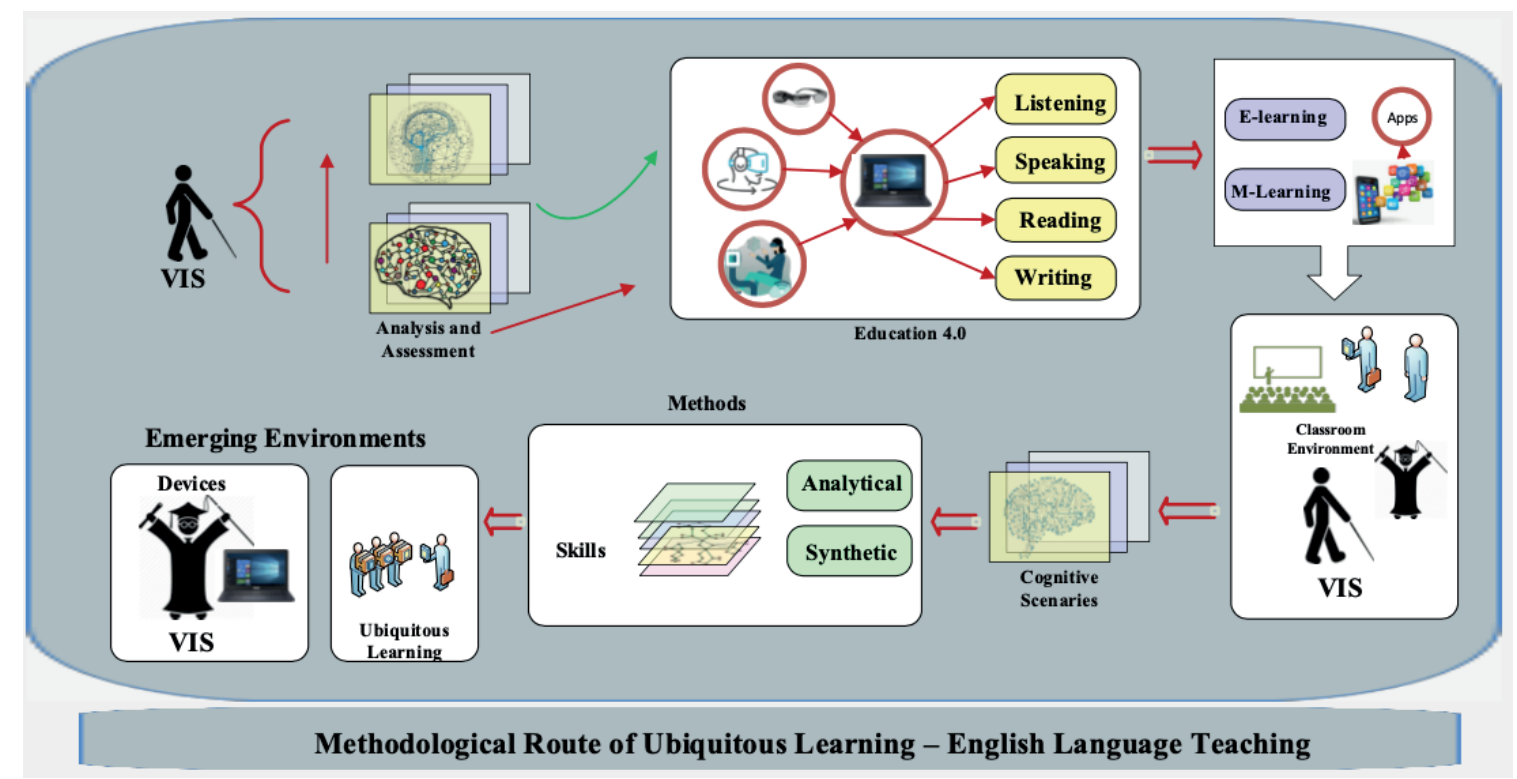

Source: authors

Figure 3 shows the road map proposed into this paper, where the VIS must start at the beginning of the academic process in the English language learning. This process includes an analysis and assessment of the VIS's skills, and the usage and typhlotechnical tools that have been acquired previously in their schooling process, for example, management skills of several programs such as: Microsoft Word, PDF, Audiobooks, computer use, smart cell phones, which are exclusively a direct and necessary support for communication and interaction of the VIS.

Identified their strengths, different didactic resources previously adapted, studied and validated according to their needs are provided by The English Language Institute with the goal of getting their immediate inclusion; the usage of emerging technologies such as Orcam My Eyes, screen readers Jaws or Nvda, some applications for transforming text into Mp3 sound format such as the Balabolca program and the use of computers, make up the different elements and tools that facilitate VIS's navigation, movement and handling of material for the development of different skills both receptive (listening and reading) and productive (speaking and writing) for functional and meaningful learning. 
We must clarify that the competence of reading, due to its particularity in the VIS is transformed into a complementary pedagogical resource; in addition to the existing ones such as the Braille system, which was limited to the exclusive usage of those who knew it (teacher had to know Braille to be able to teach) this skill that is directly incorporated into the receptive competence of reading through listening skill.

This process is directly supported through the application of various methods and techniques required in an academic process and even more, in the learning of the English language by VIS; however, for the present project we are going to refer to two very important aspects: the first is the use of the E-learning platform, which guarantees the accessibility and navigation of the VIS and it represents a direct connection with the knowledge learned, feedback and applied.

It also allows the incorporation of previously unattainable activities such as writing skills, this learning environment softens some schemes of struggle between the VIS and the digital gap, because the VIS can explore the academic and entertainment environment put on the Web. In addition to, they can support what has learned through written evidence, conversations, and other supporting academic activities.

On the other hand, Internet access becomes its main support, with the use of M-learning (apps), this application contributes to a mutual support, linked to E-learning with a primary objective that is to enable constant learning through interaction between teachers and students, between students and tutors or students and their peers, between students and their families or directly with society, thus developing different cognitive scenarios.

The VIS use the analytical method to establish concepts, through the free association of abstract ideas plus what is configured in their environment, in this way, the concepts are attached to the common reality, thanks to the support of the teacher who reinforces these elements synthesizing the knowledge received and making it practical.

The applicability of the analytical-synthetic method has allowed us to have the important academic support, that has facilitated to identify the abilities, skills and strengths of the VIS, managing to obtain an important information to implement the strategies and necessary adjustments according to the students' needs and getting an ubiquitous learning.

It is considered that the present work represents a pioneering and original idea based on universal communication, where the teacher and student use the same language that facilitates a participative interrelation and pedagogical accompaniment through the use of new tiflotechnical resources without comparison with other similar proposals that limited the development of some communicative abilities.

\section{Discussion and results}

The possibilities which were offered to the VIS by the Language Institution of the UPS using emerging technologies to take academic programs based on the English language allowed a greater likelihood of achieving their inclusion and increase their range of possibilities to enter and generate jobs, entrepreneurship and new proposals for inclusion in the field of employment for people with visual impairment.

The qualitative results described in table I relate to the application of this work system. It is important to warn that the process of adaptation of this system requires a time of conditioning and familiarization with the tool, because students still use other resources such as Braille 
system or the modality of oral examination. This situation has not been eliminated, because some students use it as a methodological alternative.

Table I presents a comparative analysis of the results obtained from the experience of teaching and learning English language with emerging technologies to achieve a real inclusion of the VIS, the universe was composed of ten students, eight students from different careers and two external students to the Language Institute of the Salesian Polytechnic University.

The eight students fulfilled the academic requirement four English levels of their university careers and two external students completed their academic process of ten levels; in addition to, these students were submitted to the final examinations of degree both written and oral, before obtaining the English Language Proficiency Certificate given by the UPS; at present, they are waiting for a favorable result, which allows them to take the international exam under this system of work, that is to say, the use of tiflotechnical resources.

In obtained results, it can be evidenced that the application of this good practice has allowed to develop of effective skills and abilities in the academic process in the acquisition of knowledge of the English language, as well as, the increasing in writing skills compared to the Braille system, that it could be evaluated if the teacher knew it, otherwise its evaluation was omitted.

Table I. Comparative Indicators of the Methodological Process

\begin{tabular}{|l|l|l|l|l|l|}
\hline \multicolumn{1}{|c|}{ Indicators } & \multicolumn{1}{|c|}{$\begin{array}{c}\text { Strongly } \\
\text { disagree }\end{array}$} & Disagreeing & $\begin{array}{c}\text { Neither agree } \\
\text { nor disagree }\end{array}$ & Agree & Totally agree \\
\hline Navigation & 1 & 1 & 1 & 1 & 6 \\
\hline Accessibility & 1 & 1 & 1 & 2 & 5 \\
\hline Functionality & 1 & 1 & 1 & 3 & 4 \\
\hline Assessment & 1 & 1 & 1 & 2 & 5 \\
\hline Performance & 1 & 1 & 1 & 2 & 5 \\
\hline
\end{tabular}

Table II shows the competencies related to skills and abilities that once identified, they allow us to take important decisions regarding the need to search for, adapt, and use different emerging technologies that help and allow to develop students' cognitive areas.

The learning of the English language for the VIS has been transforming from impossible to possible, from a challenge to a daily practice with the use of different friendly software that allows a digital coexistence with the academic supports in the English language teaching. Virtual environments will be those that facilitate access to knowledge and allow interaction between all members of an academic process in the educational community.

In Table II, it can be identified that from a methodology of the analytical-synthetic type of good practices, the first place is given to competencies, then a detail is made of the different references of ubiquitous learning within education 4.0; they are sustained by using the different technologies, both emerging and ICTs software, and landing in virtual learning environments.

When it is referred to the first section of the indicators, we can find the competencies focused directly on the skills and abilities that must be identified through an initial assessment; the same that will allow us to determine or suggest the type of emerging technology necessary that can be adapted or used by the VIS before beginning his academic process in the ubiquitous learning of the English language. 
The first indicator relates to the emerging assistive technology, identifying the different cognitive aspects to be developed and that must be immersed within the curriculum for VIS; thus taking advantage of the fact that the student is the manager of his time and space to meet the demands of his academic learning process.

The second indicator is about ICTs, they mention the importance that they have had in the VIS within their process and academic development and digital coexistence in the acquisition of the English language in a learning environment. By means of using of ICTS, the VIS have reduced the pedagogical communication gap in English language learning by a large percentage and have allowed them to move towards new proposals for real work, performance of tests and examinations.

Besides, there are two students that have completed their educational process of English language using emerging technology in a higher education institution who are demanding to be taken into account for taking an international exams with the usage of tiflotechnological tools and its respective adaptations and necessary adjustments according to their special and particular requirement.

Finally, the third indicator focuses on virtual learning environments; however, it has not been possible to take full advantage in the learning of the English language, because this virtual environment wasn't friendly and functional to VIS; however, we can mention that they have been of great pedagogical help to other types of students with different disabilities.

Table II. Analytical-synthetic Indicators of Good Practice

\begin{tabular}{|c|l|l|l|}
\hline \multirow{2}{*}{ Competencies } & \multicolumn{3}{|c|}{ Ubiquitous Learning and Education 4.0 references } \\
\cline { 2 - 4 } & Emerging Technology & ICTS - Software & Virtual Environments \\
\hline Abilities & Cognitive & Digital life & Problem formulation \\
\hline Skills & Time management & Program Operation & classmates Interaction \\
\hline
\end{tabular}

Table III warns the base line to get a route map for English teachers who work with VIS, the strategy is based on a methodology of good practices through experiences lived in a learning environments that have been initially qualified, but they need to be quantified in future work to show the efficiency of the processes applied.

As we can see the roadmap for English language teachers, it is addressed to the cognitive aspect of the teaching-learning process of the English language. The first indicator refers to assessment and evaluation. During this process, the teacher needs to be trained in the different ways and forms of VIS's evaluation, due to, they do not only carry out a conversation; it has to be an holistic evaluation of their competencies, using typhotechnological tools and emerging technologies such as those mentioned above.

The second indicator refers to the different methodological strategies that were used during the academic process, the Good Practices Methodology used through the adaptation of all academic support materials about teaching of the English language. This adaptation must be carried out with certain rigidity and following a logical process, all didactic and support resources must be transformed from a word processor (Microsoft Word), omitting all formats such as photos, images, columns, tables and other components that screen readers cannot identify or read; re-edit all the information always comparing with the original text.

In case of photographs, the instructions should be adapted in a simple way to the context of the photo, It must be written all the exercises and activities vertically and leave a space to 
complete, avoid tabulations, unnecessary signs to favor navigation with screen readers; it is recommended to use ellipsis (3 periods) after each space, in order to indicate to the VIS the place where to complete or answer; to leave a blank space at the end, after each option to choose so that the student places the letter $\mathrm{R}$ (for right) in his/her answer; the material should have reference of hyperlinks for an easy navigation through the different files; the support material of verbs should be realized in excel format.

Once, the adapted and complementary didactic resources had been compiled, they were validated with visual impairment people who have knowledge of the English language and work for "Tiflobiblioteca" at UPS; However, it might be happened that blind people may or may not have knowledge of the English language, the aim is to validate and ensure its operability, functionality, accessibility and easy navigation between the different files adjusted and adapted to facilitate their learning of the English language.

The third indicator refers to the objectives to be reached through this road map; and its main objective is to achieve autonomy in VIS's learning. Finally, the last indicator refers to the different competences and skills (listening, speaking, reading, and writing) that VIS must achieve during their academic process in the learning of the English language.

Inclusive education in any learning area must be adapted to the students' needs in order to facilitate and strengthen their academic process, which is so important for their personal and professional development.

Table III. Route Map for English Language Teachers

\begin{tabular}{|c|l|l|l|}
\hline \multirow{2}{*}{ Assessment } & \multicolumn{3}{|c|}{ Cognition of VIS's skills and abilities } \\
\cline { 2 - 4 } & Strategies & Objectives & Skills \\
\hline Interviews & Information channels & Scenarios for each VIS & emphasis on learning \\
\hline $\begin{array}{c}\text { Practical, theoreti- } \\
\text { cal and written test of } \\
\text { pre-knowledge }\end{array}$ & $\begin{array}{l}\text { Questions } \\
\text { and Answers }\end{array}$ & Indicators & Trends \\
\hline
\end{tabular}

\section{Conclusions and recommendations}

The methodological experience in the teaching-learning process of the English language with the use of emerging technologies with VIS has provided a road map for teachers, students, and family members to incorporate adequate and functional plans within a curricular alignment, which make possible a true inclusion in both cases educational and social level, with a pragmatism and a social responsibility, opening a range of opportunities in productive environments during or after finishing their university career.

The methodological strategy based on Good Practices has incorporated a base line to generate a road map to English language teachers, which helps to reduce time and improve communication and effectiveness conditions to increase VIS's potentialities in the English language into an environment shared among all students and it provides the opportunity to access to an international assessment.

Nowadays, Teachers must develop and adapt their methodological strategies around the VIS's reality and they have to know how to incorporate the emerging technologies, which can be used in a ubiquitous learning environment. 
The application of emerging technologies in the English language teaching process depends on the assessment and analysis of the VIS's needs and strengths; on the accompaniment and guidance that the teachers must give to the students, on the economic situation to afford an emerging technology and on how to make appropriate use of it to get a meaningful learning and achieving the proposed objective in the development of the different competencies and skills of the VIS.

Future works must incorporate to the proposed methodology, a new system to articulate to international assessment from different organisms to reach a real international inclusion for VIS, because at present, it contemplates only the traditional braille system by a stimulus of the sense of touch, in contrast with the current technological tools that allows another stimulus by the sense of hearing, which incorporates the acquisition of the knowledge of the English language in the shortest time for the VIS considering the four English skills.

\section{Acknowledgements}

This work has been produced within the framework of the Postgraduate Program in Special Education and thanks to the support of the GIREI - Research Group on Intelligent Electrical Networks; GEI - Research Group on Inclusive Education, Psy. Cristian Castañeda Visual Impairment Worker into "La Tiflobiblioteca" at Salesian Polytechnic University and the RED-IUS Electrical Networks and Intelligent Cities - RECI.

\section{References}

Agarwal, R., Ladha, N., Agarwal, M., Das, A., Kumar, S., Nayak, S., ... Saha, H. N. (2017). Low cost ultrasonic smart glasses for blind. 2017 8th IEEE Annual Information Technology, Electronics and Mobile Communication Conference (IEMCON), 210-213.

Bai, J., Lian, S., Liu, Z., Wang, K., y Liu, D. (2018). Virtual-Blind-Road Following-Based Wearable Navigation Device for Blind People. IEEE Transactions on Consumer Electronics, 64 (1), 136-143. https://doi.org/10.1109/TCE.2018.2812498

Chen, L., Member, S., Su, J., Chen, M., y Chang, W. (2019). An Implementation of an Intelligent Assistance System for Visually Impaired / Blind People. 2019 IEEE International Conference on Consumer Electronics (ICCE), 1-2.

Chessa, M., Noceti, N., Odone, F., Solari, F., Sosa-garcía, J., y Zini, L. (2016). An integrated artificial vision framework for assisting visually impaired users. Computer Vision and Image Understanding, 149, 209-228. https://doi.org/10.1016/j.cviu.2015.11.007

Hamam, H., y Cheikhrouhou, O. (2012). WEB BASED INTERACTIVE PLATFORM FOR. International Conference on Education and ELearning Innovations, 1-3. https://doi.org/10.1109/ICEELI.2012.6360662

Inga, E., y Hincapié, R. (2015). CREACIÓN DE ARTíCULOS ACADÉMICOS BASADOS EN PRODUCCIÓN CIENTÍFICA EN INGENIERÍA CREATION OF ACADEMIC ARTICLESBASED ON DATA MINING AND. Revista Educación En Ingeniería, 10, 65-74.

Jeong, K. (2017). University Students ' Perception and Motivation of Using Digital Applications as Effective English Learning Tools. 2017 International Conference on Platform Technology and Service (PlatCon), 1-4. https://doi.org/10.1109/PlatCon.2017.7883735

Johnson, H., Mcnally, S., Rolfe, H., Ruiz-valenzuela, J., Savage, R., Vousden, J., y Wood, C. (2019). Teaching assistants, computers and classroom management. Labour Economics, 58 (October 2018), 21-36.

Kocyigit, N., y Artar, P. S. (2015). A Challenge: Teaching English to Visually-impaired Learners. Procedia-Social and Behavioral Sciences, 199, 689-694. https://doi.org/10.1016/j.sbspro.2015.07.599

Lan, F., Zhai, G., y Lin, W. (2015). Lightweight Smart Glass System with Audio Aid for Visually Impaired People The Smart Glass System. TENCON 2015-2015 IEEE Region 10 Conference, 1-4. https://doi.org/10.1109/TENCON.2015.7372720

Lin, C., Lin, J., Lin, C., Jao, H., Chuang, L., y Wu, T. (2018). Performance Evaluation of Surrounding Image Display in Smart Glasses using Image Overlay Method. 2018 IEEE International Conference on Consumer Electronics-Taiwan (ICCE-TW), 1-5. https://doi. org/10.1109/ICCE-China.2018.8448938

Man, L. I. U. (2014). The Design of Mobile Learning System for English Based on $3 \mathrm{G}$ platform. 2014 IEEE Workshop on Advanced Research and Technology in Industry Applications (WARTIA), 767-770. https://doi.org/10.1109/WARTIA.2014.6976383

Mangalathu, S., Burton, H., Bauchy, M., Smedskjaer, M. M., y Tandia, A. (2018). Predicting the dissolution kinetics of silicate glasses using machine learning. Journal of Non-Crystalline Solids, 487 (February): 37-45.

Miah, R. (2018). A Unique Smart Eye Glass for Visually Impaired People. 2018 International Conference on Advancement in Electrical and Electronic Engineering (ICAEEE), 1-4.

Mitra, B., y Cheruvu, A. (2015). 2015 IEEE Seventh International Conference on Technology for Education Mobile Learning: A Pedagogical Framework to Facilitate Distributed Learning through Collaborative approach for Enhancing English Language 
Communication Skills. 2015 IEEE Seventh International Conference on Technology for Education (T4E): 91-94. https://doi. org/10.1109/T4E.2015.20

Moon, J. I. (2015). ScienceDirect Groping for a new English teaching strategy *. Pacific Science Review, 16(2014), $207-211$.

Morgan, P. L., Farkas, G., Hillemeier, M. M., Wang, Y., Mandel, Z., Dejarnett, C., y Maczuga, S. (2019). Are students with disabilities suspended more frequently than otherwise similar students without disabilities? III. Journal of School Psychology, 72 (November 2018): 1-13.

Muttaqin, G. F., y Suwandi, I. S. (2011). Simulation System of Color Blind Glasses by Image Processing. Proceedings of the 2011 International Conference on Electrical Engineering and Informatics (July): 1-4. https://doi.org/10.1109/ICEEl.2011.6021616

Piper, B., Bulat, J., Kwayumba, D., Oketch, J., y Gangla, L. (2019). International Journal of Educational Development Measuring literacy outcomes for the blind and for the deaf : Nationally representative results from Kenya. International Journal of Educational Development, 69 (Mayo): 1-8.

Riyanto, Y. E., y Zhang, J. (2013). The impact of social comparison of ability on pro-social behaviour Ill. The Journal of Socio-Economics, 47: 37-46.

Rizal, S., y Wan, A. (2013). Survey on Outdoor Navigation System Needs for Blind People. 2013 IEEE Student Conference on Research and Developement (December): 144-148. https://doi.org/10.1109/SCOReD.2013.7002560

Roy, S., y Ghosh, I. (2019). A new Assistive Technology in Android Platform to aid Vocabulary Knowledge Acquirement in Indian Sign Language for better Reading Comprehension in L2 and Mathematical Ability. 2019 6th International Conference on Signal Processing and Integrated Networks (SPIN), 408-413.

Simões, W. C. S. S., Jr, V. F. D. L., y Member, S. (2016). Blind User Wearable Audio Assistance for Indoor Navigation Based on Visual Markers and Ultrasonic Obstacle Detection. 2016 IEEE International Conference on Consumer Electronics (ICCE) Blind, 6063. https://doi.org/10.1109/ICCE.2016.7430522

Tang, X., y Pan, Q. (2008). Study on the Application of Blended Learning in the College English Course. 2008 International Seminar on Future Information Technology and Management Engineering, 133-136. https://doi.org/10.1109/FITME.2008.65

Wei, D. (2014). The English Learning System Design Based on the Android Platform Smart phone Android server Web server Data server Tablet Resource server. 2014 IEEE Workshop on Advanced Research and Technology in Industry Applications (WARTIA), 777-780. https://doi.org/10.1109/WARTIA.2014.6976386

Zhou, M., y Zhou, B. (2017). An IOT system design for blind. 2017 14th Web Information Systems and Applications Conference 2017 14th Web Information Systems and Applications Conference An, 992. https://doi.org/10.1109/WISA.2017.72 